\title{
Front Matter: Volume 8094
}

, "Front Matter: Volume 8094," Proc. SPIE 8094, Nanophotonic Materials VIII, 809401 (22 September 2011); doi: 10.1117/12.905032

SPIE Event: SPIE NanoScience + Engineering, 2011, San Diego, California, United SPIE. States 


\title{
PROCEEDINGS OF SPIE
}

\section{Nanophotonic Materials VIII}

\author{
Stefano Cabrini \\ Taleb Mokari \\ Editors
}

\section{4-25 August 2011 \\ San Diego, California, United States}

Sponsored by

SPIE

Cosponsored by

Air Live (Taiwan)

Fruhmann GmbH NTL Manufacturer \& Wholesaler (Austria)

Published by

SPIE 
The papers included in this volume were part of the technical conference cited on the cover and title page. Papers were selected and subject to review by the editors and conference program committee. Some conference presentations may not be available for publication. The papers published in these proceedings reflect the work and thoughts of the authors and are published herein as submitted. The publisher is not responsible for the validity of the information or for any outcomes resulting from reliance thereon.

Please use the following format to cite material from this book:

Author(s), "Title of Paper," in Nanophotonic Materials VIII, edited by Stefano Cabrini, Taleb Mokari, Proceedings of SPIE Vol. 8094 (SPIE, Bellingham, WA, 2011) Article CID Number.

ISSN 0277-786X

ISBN 9780819487049

Published by

SPIE

P.O. Box 10, Bellingham, Washington 98227-0010 USA

Telephone +1 3606763290 (Pacific Time) · Fax +1 3606471445

SPIE.org

Copyright () 2011, Society of Photo-Optical Instrumentation Engineers

Copying of material in this book for internal or personal use, or for the internal or personal use of specific clients, beyond the fair use provisions granted by the U.S. Copyright Law is authorized by SPIE subject to payment of copying fees. The Transactional Reporting Service base fee for this volume is $\$ 18.00$ per article (or portion thereof), which should be paid directly to the Copyright Clearance Center (CCC), 222 Rosewood Drive, Danvers, MA 01923. Payment may also be made electronically through CCC Online at copyright.com. Other copying for republication, resale, advertising or promotion, or any form of systematic or multiple reproduction of any material in this book is prohibited except with permission in writing from the publisher. The CCC fee code is 0277-786X/11/ \$18.00.

Printed in the United States of America.

Publication of record for individual papers is online in the SPIE Digital Library.

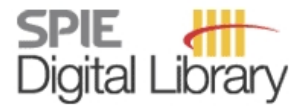

SPIEDigitalLibrary.org

Paper Numbering: Proceedings of SPIE follow an e-First publication model, with papers published first online and then in print and on CD-ROM. Papers are published as they are submitted and meet publication criteria. A unique, consistent, permanent citation identifier (CID) number is assigned to each article at the time of the first publication. Utilization of CIDs allows articles to be fully citable as soon as they are published online, and connects the same identifier to all online, print, and electronic versions of the publication. SPIE uses a six-digit CID article numbering system in which:

- The first four digits correspond to the SPIE volume number.

- The last two digits indicate publication order within the volume using a Base 36 numbering system employing both numerals and letters. These two-number sets start with 00, 01, 02, 03, 04 , $05,06,07,08,09,0 A, 0 B \ldots$. OZ, followed by 10-1Z, 20-2Z, etc.

The CID number appears on each page of the manuscript. The complete citation is used on the first page, and an abbreviated version on subsequent pages. Numbers in the index correspond to the last two digits of the six-digit CID number. 


\section{Contents}

vii Conference Committee

SESSION 1 SYNTHESIS AND CHARACTERIZATION I

809403 Silanization of plasma-grown silicon quantum dots for production of a tunable, stable, colloidal solution [8094-02]

I. E. Anderson, R. A. Shircliff, Colorado School of Mines (United States); B. G. Lee, National Renewable Energy Lab. (United States); B. Simonds, S. Agarwal, Colorado School of Mines (United States); P. Stradins, National Renewable Energy Lab. (United States); R. T. Collins, Colorado School of Mines (United States)

809404 Development of precise tuning method of inter-dot spacing and resonant energy transfer between Au clusters [8094-03]

M. Inada, Y. Yoshihara, H. Kawasaki, Y. Iwasaki, T. Saitoh, Kansai Univ. (Japan); I. Umezu, A. Sugimura, Konan Univ. (Japan)

809405 Si quantum dots and different aspects of applications (Invited Paper) [8094-04]

T. V. Torchynska, Instituto Politécnico Nacional (Mexico)

\section{SESSION 2 SYSTEMS AND MEASUREMENTS I}

809407 Photocathode performance improvement by plasmonic light trapping in nanostructured metal surfaces [8094-06]

A. Polyakov, K. Thompson, Lawrence Berkeley National Lab. (United States) and Univ. of California, Berkeley (United States); C. Senft, S. Dhuey, B. Harteneck, X. Liang, J. P. Schuck, S. Cabrini, W. Wan, H. A. Padmore, Lawrence Berkeley National Lab. (United States)

809409 Stability of organic nanowires [8094-08]

F. Balzer, M. Schiek, Univ. of Southern Denmark (Denmark); I. Wallmann, A. Schäfer, A. Lützen, Rheinische Friedrich-Wilhelms-Univ. Bonn (Germany); H.-G. Rubahn, Univ. of Southern Denmark (Denmark)

\section{SESSION 3 SYSTEMS AND MEASUREMENTS II}

8094 OB Surface patterning for light extraction in luminescent sol-gel films [8094-10]

A. Revaux, G. Dantelle, L. Devys, Lab. de Physique de la Matière Condensée, CNRS, Ecole Polytechnique (France); H. Benisty, Lab. Charles Fabry, Institut d'Optique, CNRS, Univ. Paris Sud 11 (France); T. Gacoin, J. P. Boilot, Lab. de Physique de la Matière Condensée, CNRS, Ecole Polytechnique (France)

8094 OD Structural and vibrational properties of Mg doped ZnO alloy nanostructures [8094-12]

B. Karthikeyan, T. Pandiyarajan, National Institute of Technology, Tiruchirappalli (India) 
8094 OE Structural fluorescence in the butterfly Morpho sulkowskyi (Nymphalidae) [8094-13]

E. Van Hooijdonk, Univ. of Namur (FUNDP) (Belgium) and Institut des NanoSciences de Paris, CNRS, Pierre and Marie Curie Univ. (France); C. Barthou, Institut des NanoSciences de Paris, CNRS, Pierre and Marie Curie Univ. (France); J. P. Vigneron, Univ. of Namur (FUNDP) (Belgium); S. Berthier, Institut des NanoSciences de Paris, CNRS, Pierre and Marie Curie Univ. (France)

8094 OF Photo-induced self-organized pattern formation in bio-synthesized nanomaterials [8094-14] N. V. Kukhtarev, T. Kukhtareva, F. Okafor, A. Johnson, Alabama A\&M Univ. (United States)

8094 OG Multi-color reflection from chiral thin-film stacks [8094-15]

D. J. Brink, N. van der Berg, L. Prinsloo, Univ. of Pretoria (South Africa)

$8094 \mathrm{OH}$ Nanoarchitecture in the black wings of Troides magellanus: a natural case of absorption enhancement in photonic materials [8094-16]

A. Herman, C. Vandenbem, O. Deparis, P. Simonis, J. P. Vigneron, Facultes Univ. Notre Dame de la Paix (Belgium)

\section{SESSION 5 SYNTHESIS AND CHARACTERIZATION II}

8094 Ol Photoluminescence of CulnS2 nanocrystals: effect of surface modification [8094-17] Y.-K. Kim, Y.-S. Cho, K. Chung, C.-J. Choi, Korea Institute of Materials Science (Korea, Republic of)

8094 0J Nearly total optical extinction in arrays of non-resonant nanorods [8094-18] P. Ghenuche, Lab. de Photonique et Nanostructures, CNRS (France) and ONERA (France); G. Vincent, ONERA (France); M. Laroche, Lab. Charles Fabry, Institut d'Optique, CNRS, Univ. Paris-Sud (France); N. Bardou, Lab. de Photonique et Nanostructures, CNRS (France); R. Haïdar, ONERA (France); J.-L. Pelouard, S. Collin, Lab. de Photonique et Nanostructures, CNRS (France)

8094 OM Photoluminescence from silicon nitride alloys [8094-21]

J. Kistner, M. B. Schubert, J. H. Werner, Univ. Stuttgart (Germany)

\section{POSTER SESSION}

809400 Optical, phonon and structural analysis of Na doped ZnO nanostructures [8094-23] T. Pandiyarajan, B. Karthikeyan, National Institute of Technology, Tiruchirappalli (India)

8094 OP Synthesis of tin oxide, indium oxide and tin-doped indium oxide nanowires by chemical vapor deposition [8094-24]

K. K. Wong, M. K. Fung, Y. C. Sun, X. Y. Chen, A. M. C. Ng, A. B. Djurišic, W. K. Chan, The Univ. of Hong Kong (Hong Kong, China)

$80940 Q$ Optical and vibrational studies of surface modified ZnO nanostructures [8094-25] T. Pandiyarajan, R. Nagalakshmi, B. Karthikeyan, National Institute of Technology, Tiruchirappalli (India) 
$8094 \mathrm{OR} \quad \mathrm{Gd}^{3+}$ and $\mathrm{S}^{2+}$ sensitizer effect on the upconversion emission of $\mathrm{ZrO}_{2}: \mathrm{Yb}^{3+}$, $\mathrm{Er}^{3+}$ nanocrystals prepared by precipitation method with a hydrothermal process [8094-26]

A. Urbina-Frías, E. De La Rosa, T. López-Luke, Ctr. de Investigaciones en Óptica (Mexico); P. Salas, Univ. Nacional Autónoma de México (Mexico); C. Angeles-Chavez, Instituto

Mexicano del Petróleo (Mexico); A. Torres, Univ. Autónoma de Nuevo León (Mexico)

8094 OS Temperature and frequency dependent admittance of InAs self-assembled quantum dots embedded in GaAs [8094-28]

A. Sellai, Sultan Qaboos Univ. (Oman); A. Mesli, IM2NP, CNRS, Aix-Marseille Univ. (France); P. Kruszewski, Institute of Physics Polish Academy of Sciences (Poland); A. R. Peaker, M. Missous, The Univ. of Manchester (United Kingdom)

Author Index 
Downloaded From: https://www.spiedigitallibrary.org/conference-proceedings-of-spie on 25 Apr 2023

Terms of Use: https://www.spiedigitallibrary.org/terms-of-use 


\title{
Conference Committee
}

\author{
Symposium Chairs
}

David L. Andrews, University of East Anglia Norwich (United Kingdom) James G. Grote, Air Force Research Laboratory (United States)

Conference Chairs

Stefano Cabrini, Lawrence Berkeley National Laboratory (United States)

Taleb Mokari, Ben-Gurion University of the Negev (Israel)

Program Committee

David L. Andrews, University of East Anglia Norwich (United Kingdom)

Angus J. Bain, University College London (United Kingdom)

Mireille H. Blanchard-Desce, Université de Rennes 1 (France)

Robert W. Boyd, University of Rochester (United States)

Zeno Gaburro, Università degli Studi di Trento (Italy)

Aaron W. Harper, The University of Southern California (United States)

Ghassan E. Jabbour, Arizona State University (United States)

François Kajzar, Université d'Angers (France)

Dmitri I. Kovalev, University of Bath (United Kingdom)

Paras N. Prasad, University at Buffalo (United States)

Dmitri Talapin, The University of Chicago (United States)

Younan Xia, Washington University in St. Louis (United States)

\section{Session Chairs}

1 Synthesis and Characterization I

Stefano Cabrini, Lawrence Berkeley National Laboratory (United States)

2 Systems and Measurements I

Matthew A. Pelton, Argonne National Laboratory (United States)

3 Systems and Measurements II

Luca Dal Negro, Boston University (United States)

$4 \quad$ Bio-Organic Materials

Tetyana V. Torchynska, Instituto Politécnico Nacional (Mexico)

5 Synthesis and Characterization II

Jingyu Zhang, Lawrence Berkeley National Laboratory (United States) 
Downloaded From: https://www.spiedigitallibrary.org/conference-proceedings-of-spie on 25 Apr 2023

Terms of Use: https://www.spiedigitallibrary.org/terms-of-use 